\title{
ANALISIS FAKTOR RESIKO KEJADIAN OBESITAS PADA REMAJA DI KOTA GORONTALO
}

\author{
Ramly Abudi ${ }^{1}$, Irwan $^{2}$ \\ ${ }^{1,2}$ Program studi Kesehatan masyarakat Universitas Negeri Gorontalo, Indonesia \\ irwandel@yahoo.com
}

\begin{abstract}
ABSTRAK
Menurut World Health Organization (WHO) 2006, secara global terdapat lebih dari satu milyar penduduk dewasa yang kelebihan berat badan (gemuk), 300 juta diantaranya kegemukan (obes). Sejak tahun 1980 dibeberapa wilayah di Amerika Utara, Inggris, Eropa Timur, Timur Tengah, Kepulauan Pasifik, Australia dan Cina, jumlah penduduk yang menderita kegemukan berlipat tiga kali. Sebuah penelitian terbaru yang dipublikasikan dalam American Journal of Epidemiology, mengungkapkan, obesitas yang dialami seseorang pada saat remaja berkaitan erat dengan peningkatan risiko kematian di usia paruh baya.Penelitian tersebut melibatkan 227 ribu pria dan wanita Norwegia yang diukur tinggi dan berat badannya antara tahun 1963-1975 saat mereka berusia antara 14 -19 tahun, dengan mengikuti perkembangan mereka sampai tahun 2004, saat mereka rata-rata berusia 52 tahun, 9.650 orang diantaranya meninggal. Dari hasil penelitian diketahui bahwa mereka yang mengalami obesitas atau overweight (kelebihan berat badan) saat remaja diketahui 3-4 kali lebih beresiko mengalami penyakit jantung yang berujung pada kematian. Resiko kanker kolon serta penyakit pernapasan asma dan emfisema juga meningkat 2-3 kali (Anonymous, 2008).
\end{abstract}

Kata Kunci; Faktor kejadian Obesitas

\begin{abstract}
Según la Organización Mundial de la Salud (OMS) en 2006, en todo el mundo hay más de mil millones de la población adulta tiene sobrepeso (obesidad), 300 millones tienen sobrepeso (obesidad). Desde 1980 algunas zonas de América del Norte, el Reino Unido, Europa del Este, Oriente Medio, las islas del Pacífico, Australia y China, el número de personas que sufren de obesidad se triplicaron. Un reciente estudio publicado en el American Journal of Epidemiology, dijo la obesidad experimentado por una persona durante la adolescencia está estrechamente relacionado con un mayor riesgo de muerte en el baya.Penelitian edad con 227 mil hombres y mujeres Noruega altura y peso entre los años 1963- mide 1975 cuando tenían entre 14 -19 años, a raíz de su progreso hasta 2004, cuando el promedio de edad fue de 52 años, 9.650 de ellos muertos. Los resultados del estudio revelaron que aquellos que son obesos o con sobrepeso (sobrepeso) como un adolescente conocido a 3-4 veces mayor riesgo de enfermedades del corazón que resulta en la muerte. El riesgo de cáncer de colon y las enfermedades respiratorias como el asma y enfisema también aumentó 2-3 veces (Anónimo, 2008).
\end{abstract}

Palabras clave Factor de Obesidad 


\section{Pendahuluan}

Dalam 15 tahun terakhir telah terjadi transisi epidemiologi (SKRT, 1986-2001), yang ditandai oleh adanya pergeseran proporsi kematian yang tinggi dari kelompok usia muda ( $<4$ tahun) ke kelompok umur tua ( $>55$ tahun), pergeseran perubahan penyakit penyebab kematian, proporsi kematian karena penyakit infeksi menurun, proporsi kematian karena penyakit degeneratif dan pembuluh darah, neoplasma serta endokrin meningkat 2-3 kali lipat. Kegemukan dan obesitas merupakan salah satu faktor risiko timbulnya penyakit degeneratif sebagai akibat dari perubahan gaya hidup, perubahan pola makan ke arah tinggi karbohidrat, lemak dan garam serta rendah serat serta rendahnya aktifitas fisik yang dilakukan seharihari (Azwar,A).

Prevalensi kegemukan di Indonesia relatif tinggi. Penelitian kodyat dkk (1996) terhadap 10.459 orang umur 18 tahun ke atas di 12 kotamadya di Indonesia pada tahun 1996 menunjukkan bahwa yang menderita kegemukan sebanyak 22,5\%, yang 54,2\% di antaranya menderita kegemukan tingkat berat (obesitas). Bila dilihat menurut jenis kelamin, ternyata perempuan sebesar $26,1 \%$ dan laki-laki 8,5jam/hari - Sarapan
15,7\%. Bila dilihat menurut jenis pekerjaan, pegawai negeri sipil (PNS) sebesar 27,3\% termasuk gemuk. ABRI (dulu belum dipisah TNI dan Polisi) sebesar 26,4 diantaranya termasuk gemuk. Di antara wiraswasta sebesar 26,5\% termasuk gemuk. Bila hanya dilihat kelompok umur, 41-55 tahun ternyata prevalensi gemuknya lebih tinggi, yaitu dari 2.586 orang sebesar $33,7 \%$, yang 59,0\% di antaranya termasuk obesitas (Anonymous, 2004). Beberapa penelitian terakhir menunjukkan bahwa penyebab kegemukan dan obesitas bersifat multi- faktor, antara lain adanya keterlibatan faktor genetik, Berdasarkan hasil Riskesdas yang dilakukan di seluruh kabupaten/kota seprovinsi Gorontalo pada tahun 2007, menunjukkan prevalensi obesitas umum (berat badan lebih + obesitas) pada penduduk dewasa (15 tahun ke atas), yaitu kabupaten Boalemo 20,4\%, kabupaten Gorontalo 26,5\%, kabupaten Pohuwato 19,7\%, kabupaten Bone Bolango 24,6\% dan kota Gorontalo 34,9\% (Riskesdas Gorontalo,2007).

\section{Metode Penelitian}

Jenis penelitian yang digunakan adalah penelitian observasional analitik dengan rancangan kasus kelola (case control study), Perkiraan Besar Sampel 75 orang. 


\section{Hasil penelitian}

Pengumpulan data dilakukan dengan dua tahap, tahap pertama dilakukan pengumpulan data antropometri dan umur siswa, sebagai data screening dalam rangka untuk menentukan siswa yang tergolong obesitas dan non obesitas. Jumlah siswa yang berhasil diukur sebanyak 1963 siswa yaitu untuk SMU Negeri 1 Gorontalo berjumlah 796 siswa dan SMU

Tabel 13. Jumlah Siswa yang di Screening

\begin{tabular}{|l|c|c|}
\hline $\begin{array}{l}\text { ASAL } \\
\text { SEKOLAH }\end{array}$ & $\begin{array}{l}\text { JUMLAH } \\
\text { SISWA }\end{array}$ & $\begin{array}{l}\text { SISWA } \\
\text { DIUKUR }\end{array}$ \\
\hline $\begin{array}{l}\text { SMU Negeri } \\
1 \text { Gorontalo }\end{array}$ & 1346 & 796 \\
\hline $\begin{array}{l}\text { SMU Negeri } \\
\text { 3 Gorontalo }\end{array}$ & 1301 & 1167 \\
\hline JUMLAH & $\mathbf{2 6 4 7}$ & $\mathbf{1 9 6 3}$ \\
\hline
\end{tabular}

1. Deskriptif Status Gizi dan Kejadian Obesitas

Berdasarkan hasil screening yaitu pengukuran tinggi badan dan berat badan, dari 1.963 siswa sekolah menengah atas yang diukur, menunjukkan bahwa distribusi status gizi anak sekolah menengah atas di 2 (dua) sekolah menengah atas kota Gorontalo, status gizi kurang (underweight), 949 siswa $(48,34 \%)$ status gizi baik (normal), 139 siswa $(7,08 \%)$ gizi lebih (overweight) dan $200(10,19 \%)$ siswa yang mengalami obesitas menunjukkan bahwa dari 1.963 siswa yang berhasil di screening diperoleh jumlah siswa berjenis kelamin perempuan (1.212 siswa) lebih banyak dibandingkan dengan siswa berjenis kelamin laki-laki (751 siswa). Dari jumlah laki-laki yang di screening, yang obesitas sebanyak 81 siswa $(10,79 \%)$ dan dari jumlah perempuan yang di screening yang obesitas sebanyak 119 siswa $(9,82 \%)$. Setelah dilakukannya screening maka langkah selanjutnya adalah melakukan pengumpulan data tahap kedua. Tapi sebelumnya dilakukan penarikan sampel terhadap siswa sekolah menengah atas yaitu sebanyak 75 siswa sebagai kasus dalam hal ini yang obesitas dan 75 siswa sebagai kontrol (normal). Berdasarkan Umur pada Anak Sekolah Menengah Atas di Kota Gorontalo $10.00 \% \quad 34.00 \%$ $23.50 \% \quad 30.00 \% \quad 2.50 \% 14$ Tahun 15 Tahun 16 Tahun 17 Tahun 18 Tahu1. Dari jumlah kasus di tiap sekolah yaitu SMU Negeri 1 Gorontalo (72 siswa obesitas) dan SMU Negeri 3 Gorontalo (128 siswa obesitas) dikeluarkan yang siswa yang berumur 14 tahun, 18 tahun dan 19 tahun. Dikeluarkan juga siswa yang duduk di kelas 12. Sehingga jumlah kasus untuk SMUN 1 Gorontalo 50 siswa obesitas dan SMUN 3 Gorontalo 65 siswa obesitas. 
Tabel.Distribusi Sampel berdasarkan Asal Sekolah pada Anak Sekolah Menengah Atas di Kota Gorontalo Tahun 2008

\begin{tabular}{|c|c|c|c|}
\hline $\begin{array}{c}\text { Asal } \\
\text { Sekolah }\end{array}$ & Kasus & Kontrol & Jumlah \\
\hline $\begin{array}{c}\text { SMU } \\
\text { Negeri 1 } \\
\text { Gorontalo }\end{array}$ & 33 & 33 & 66 \\
\hline $\begin{array}{c}\text { SMU } \\
\text { Negeri 1 } \\
\text { Gorontalo }\end{array}$ & 42 & 42 & 84 \\
\hline Jumlah & $\mathbf{7 5}$ & $\mathbf{7 5}$ & $\mathbf{1 5 0}$ \\
\hline
\end{tabular}

Deskripsi Variabel Penunjang variabel penunjang ini dimaksudkan untuk mengetahui seberapa besar pengaruh pendidikan, pekerjaan orang tua responden terhadap kejadian obesitas pada anak sekolah menengah atas.

\section{a. Pendidikan Orang Tua}

Gambaran tingkat pendidikan orang tua responden terhadap kejadian obesitas pada anak sekolah menengah atab. Pekerjaan Orang Tua Gambaran pekerjaan orang tua responden terhadap kejadian obesitas pada anak sekolah menengah atas, menunjukkan distribusi sampel menurut pekerjaan ayah yang terbanyak adalah PNS sebanyak 74 siswa dimana yang tinggi pada sampel kasus yaitu $56,76 \%$ dibandingkan pada sampel kontrol yaitu 43,24\%. Sedangkan untuk pekerjaan ibu responden yang terbanyak pada pekerjaan sebagai ibu rumah tangga sebanyak 98 siswa, dimana yang tinggi pada sampel kontrol yaitu 53,06\% dibandingkan pada sampel kasus yaitu 46,94\%. Dan yang sedikit pada pekerjaan sebagai pegawai Swasta yaitu 1 siswa.

\section{Analisis Bivariat}

Analisis bivariat ini dimaksudkan untuk melihat besar risiko setiap variabel independent terhadap kejadian obesitas pada anak sekolah menengah atas. menunjukkan bahwa dari 150 responden sebagian besar terdistribusi pada risiko tinggi yaitu 89 siswa (59,33\%). Pada sampel kasus yang banyak jumlahnya adalah pada risiko tinggi yaitu 54 siswa (72\%) dibandingkan dengan yang risiko rendah yaitu 21 siswa (28\%). Sedangkan pada sampel kontrol jumlahnya tinggi pada risiko rendah yaitu 40 siswa $(53,33 \%)$ dibandingkan dengan yang risiko tinggi 35 siswa $(46,67 \%)$.

5. Hasil uji statistik Odd Ratio (OR) diperoleh nilai OR 2,939 pada 95\% Confidence Interval (CI) Lower 1,492 dan Upper 5.790 dan didukung oleh nilai $\mathrm{p}$ value $0,002(0,002<0,005)$. Artinya responden yang tidak olahraga atau olahraga $<3$ kali dalam seminggu berisiko 2,939 kali dibandingkan dengan responden yang melakukan olahraga $\geq 3 \mathrm{x}$ dalam seminggu. Karena CI yang tidak mencakup nilai 1 maka dikatakan signifikan (bermakna) sehingga hipotesis di terima (H0 ditolak). Analisis Multivariat 
Analisis multivariat ini dimaksudkan untuk mengetahui variabel mana yang lebih besar pengaruhnya dengan mengontrol variabel-variabel lain pada saat yang bersamaan terhadap kejadian obesitas pada anak sekolah menengah atas di kota Gorontalo diantara variabel-variabel yang merupakan faktor risiko setelah dilakukan analisis bivariat

\section{Pembahasan}

\section{Kegiatan Olahraga}

Olahraga merupakan kebiasaan hidup dari seseorang yang akan ingin hidup sehat dengan memerlukan pergerakan otot, dan pikiran, serta dipadukan dengan aktifitas fisik. Pekerjaan yang dilakukan sehari- hari dapat mempengaruhi gaya hidup seseorang. Gaya hidup yang kurang menggunakan aktifitas fisik akan berpengaruh terhadap kondisi tubuh seseorang. Aktifitas tersebut diperlukan untuk membakar kalori dari dalam tubuh, bila pemasukan kalori berlebihan dan tidak diimbangi dengan aktifitas fisik yang seimbang akan memudahkan seseorang menjadi gemuk. Kecanggihan teknologi seperti televisi dan komputer menyebabkan banyak anak-anak dan remaja terpaku didepannya sehingga kurang melakukan permainan yang membutuhkan aktifitas fisik. Setiap tambahan satu jam menyaksikan TV di akhir pekan ketika anak usia 5 tahun meingkatkan peluang obesitas ketika ia berumur 30 tahun sebanyak 7\%. Hasil analisis faktor risiko aktifitas fisik dalam hal ini olahraga terhadap kejadian obesitas pada siswa menengah atas, didapatkan sebagian besar terdistribusi pada risiko tinggi yaitu 89 siswa $(59,33 \%)$. Pada sampel kasus yang banyak jumlahnya adalah pada risiko tinggi yaitu 54 siswa (72\%) dibandingkan dengan yang risiko rendah yaitu 21 siswa (28\%). Sedangkan pada sampel kontrol jumlahnya tinggi pada risiko rendah yaitu 40 siswa $(53,33 \%)$ dibandingkan dengan yang risiko tinggi 35 siswa (46,67\%). Hasil uji statistik Odd Ratio (OR) diperoleh nilai OR 2,939 pada 95\% Confidence Interval (CI) Lower 1,492 dan Upper 5.790 dan didukung oleh nilai $p$ value $0,002(0,002<0,005)$. Artinya responden yang tidak olahraga atau olahraga $<3$ kali dalam seminggu berisiko 2,939 kali dibandingkan dengan responden yang melakukan olahraga $\geq 3 \mathrm{x}$ dalam seminggu. Karena CI yang tidak mencakup nilai 1 maka dikatakan signifikan (bermakna) sehingga hipotesis di terima (H0 ditolak). Hasil ini mendukung penelitian yang telah dilakukan oleh George Tobing (2006) bahwa siswa yang frekuensi olahraganya rendah mempunyai risiko 1,299 kali untuk mengalami obesitas walaupun hasilnya tidak bermakna. Hasil yang sama ditemukan pada penelitian 
Azhari (2007), ada hubungan aktifitas fisik dengan obesitas $(\mathrm{OR}=$ $2,100,95 \%$ CI 1,032-4,272), yang menunjukkan siswa yang tidak aktif memiliki peluang risiko 2,100 kali lebih besar mengalami obesitas dibandingkan remaja yang aktif. Hasil wawancara mengungkapkan bahwa sebagian besar responden baik kasus (obesitas) maupun kontrol (non obesitas) selalu melakukan aktifitas rendah seperti nonton TV, main game, baca komik/buku dan bersantai, tetapi pada kelompok kasus melakukan aktifitas ini lebih lama dibandingkan pada kelompok kontrol. Disamping itu, dengan semakin majunya sarana transportasi, seperti bus, mobil, orang tidak perlu lagi jalan kaki atau bersepeda untuk berkunjung ke suatu tempat. Di tiap gedung pun terdapat sarana lift maupun eskalator yang memungkinkan aktifitas fisik seseorang semakin berkurang. Kesibukan yang semakin meningkat juga menyebabkan seseorang tidak mempunyai waktu untuk berolahraga

\section{Konsumsi Fast Food}

Kebiasaan makan dalam keluarga suka ditiru oleh anak-anak, misalnya makan yang berlebihan, frekuensi makan yang sering, kelebihan snack, dan makan diluar Waktu makan
Anak-anak maupun remaja sekarang ini lebih bayak makan makanan instan, makanan cepat saji, minuman yang mengandung tinggi gula serta makan cemilan yang sudah diproses yang tinggi kalori dan lemak namun rendah vitamin lainnya dibanding makanan sehat dan segar seperti sayur dan buah-buahan. Hasil analisis dari 150 siswa sekolah menengah atas, diperoleh nilai OR 2,705 pada 95\% Confidence Interval (CI) 1,390 5,623 dan nilai $\mathrm{p}$ value 0,003 . Artinya responden yang mengkonsumsi fast food $\geq 3 \mathrm{x}$ dalam seminggu mempunyai risiko 2,705 kali mengalami obesitas dibandingkan yang < mengkonsumsi fast food. Karena CI yang tidak mencakup nilai 1 maka variabel mengkonsumsi fast food signifikan (bermakna) terhadap kejadian obesitas pada anak sekolah menengah atas kota Gorontalo. Penelitian ini mendukung penelitian Setyaningrum (2007) yang memperlihatkan bahwa 43,4\% responden remaja usia pubertas sering mengkonsumsi makanan siap saji. Hasil penelitian memperlihatkan bahwa ada hubungan yang bermakna antara konsumsi makanan cepat saji dengan kejadian obesitas. Hal ini juga diperkuat dengan penelitian Kadim, dkk (2007) yang menunjukkan bahwa konsumsi camilan dan makanan kecil lain secara berlebih terjadinya obesitas pada anak. Makanan jenis fast food biasa tinggi lemak dan di goreng pada suhu tinggi 
Dampaknya minyak goreng yang tidak jenuh akhirnya menjadi minyak jenuh. Pemakaian minyak goreng yang berulangulang juga membuat minyak goreng tak jenuh menjadi jenuh. Jenis makanan jajanan atau makanan kesukaan siswa adalah makanan yang tinggi lemak, goreng-gorengan dan bersifat instan, seperti bakso, mie instan, nasi goreng, cokelat, roti, nasi kuning dan bakwan/pisang goreng/ tahu.

\section{Lama Tidur Malam}

Masalah kegemukan, utamanya pada anakanak ternyata tak cuma terkait dengan makanan. Sebaiknya apakah kualitas tidur pada malam hari juga memainkan peran besar dalam pertumbuhan badan seorang anak. Penelitian mutakhir oleh para ahli dari Univertas Michigan, Amerika Serikat, menyimpulkan, kualias tidur yang buruk pada malam hari terkait erat dengan munculnya obesitas pada anak.

Hasil wawancara terhadap 150 responden, sebagian besar sampel kasus maupun sampel kontrol terjadi pada siswa yang risiko tinggi, masing-masing 54 siswa $(72,00 \%)$ pada sampel kasus dan 42 siswa $(56,00 \%)$ pada sampel kontrol. Hasil analisis, diperoleh nilai OR 2,020 pada 95\% CI Lower 1,024 dan Upper 3,987 dan nilai $\mathrm{p}$ value 0,041 . Artinya responden yang lama tidur malam $<8,5$ jam/hari mempunyai risiko 2,020 kali mengalami obesitas dibandingkan yang lama tidur malam $\geq 8,5$ jam/hari. Karena CI yang mencakup nilai 1 maka variabel lama tidur malam signifikan (bermakna) terhadap kejadian obesitas pada anak sekolah menengah atas kota Gorontalo. Para peneliti mengatakan, anak-anak dengan tidur malam yang cukup dan berkualitas akan lebih aktif dalam melakukan kegiatan pada siang hari. Sebaliknya, anak-anak yang kurang tidur cenderung malas beraktifitas namun lebih banyak makan. Inilah yang membuat mereka menjadi gemuk. Kesimpulan ini sejalan dengan hasil beberapa penelitian lainnya, salah satunya riset para ahli dari Universitas Bristol, Inggris. Disebutkan, orang yang cuma tidur lima jam per malam memiliki kandungan hormon ghrelin 15 persen lebih banyak dibanding mereka yang tidur delapan jam. Ghrelin adalah hormon

yang meningkatkan sensasi rasa lapar. Tak heran, mereka yang kurang tidur jadi lebih banyak makan. Ujung-ujungnya, tubuh pun jadi gendut. Sesuai dengan hasil wawancara yang telah dilakukan, sebagian besar siswa tidur tidak mencukupi 8,5 jam, dan sebagian besar menyatakan bahwa timbul rasa lapar pada malam hari sehingga sebagian siswa mengkonsumsi cemilan sebelum tidur seperti roti dan mie 
instant. Dan sebagiannya lagi menyatakan bahwa mereka lapar tetapi menahannya.

\section{Sarapan Pagi}

Hasil analisis, diperoleh nilai OR 2,449 pada 95\%CI Lower 1,256 dan Upper 4,776 dan nilai $p$ value 0,008 . Artinya responden yang tidak sarapan pagi atau $<4$ kali dalam seminggu mempunyai risiko 2,449 kali mengalami obesitas dibandingkan yang sarapan pagi $\geq 4$ kali dalam seminggu. Karena CI yang tidak mencakup nilai 1 maka variabel sarapan pagi signifikan (bermakna) terhadap kejadian obesitas pada anak sekolah menengah atas kota Gorontalo. Secara analisis multivariat variabel sarapan pagi tetap signifikan (bermakna) dengan OR 2.196, walaupun terjadi penurunan OR yang tadinya secara bivariat OR 2,256. Terjadinya penurunan nilai OR pada analisis multivariat disebabkan adanya interaksi dari variabel- variabel berisiko sehingga variabel sarapan pagi ini melemah, tetapi masih dikatakan segnifikan. Hal ini disebabkan karena biasanya orang yang melewatkan waktu makan pagi akan menurun aktifitas kerjanya. Rasa lapar akibat tidak makan pagi akan dikompensasikan beberapa jam kemudian sehingga secara tidak sadar timbul perasaan kelaparan dan akan mencari-cari makanan cemilan ataupun makan siang yang jumlahnya jauh lebih banyak dibanding kalau sudah makan pagi sebelumnya (Wirakusumah Emma, 2001). Hal ini juga dipengaruhi oleh hasil wawancara dimana siswa yang perutnya kosong (tidak sarapan) mengganjal perutnya dengan cara mengkonsumsi cemilan yang tinggi gula dan lemak, seperti snack (o'corn, taro, ciki, leo), biskuit (malkis), goreng, ba'wan, roti cokelat dan roti keju, pop ice, mountea, frutamin, mie goreng dan mie kuah. Siswa yang tidak sarapan lebih banyak makan pada siang hari dan malam hari. Makan siang umumnya terdiri dari nasi, lauk pauk, dan sayuran tanpa menkonsumsi buah. Tetapi banyak juga yang kurang mengkonsumsi sayur. begitu pula pada malam harinya, pada sampel kasus ditambah dengan minum susu sebelum tidur. Asupan makanan yang banyak pada malam hari akan berakibat pada meningkatnya glukosa yang disimpan sebagai glikogen. Karena aktifitas fisik pada malam hari sangat rendah, glikogen kemudian disimpan dalam bentuk lemak. Siswa yang tidak sarapan lebih banyak makan pada siang hari dan malam hari. Makan siang umumnya terdiri dari nasi, lauk pauk, dan sayuran tanpa menkonsumsi buah. Tetapi banyak juga yang kurang mengkonsumsi sayur. begitu pula pada malam harinya, pada sampel kasus ditambah dengan minum susu sebelum tidur. Masih kurangnya penelitian 
yang berkaitan mengenai obesitas dengan sarapan pagi di Indonesia. Akan tetapi, hasil pada penelitian ini memperlihatkan dukungan terhadap temuan oleh castro seorang peneliti Psikologi Universitas Texas bahwa proporsi asupan pangan pagi hari berkorelasi negatif dengan asupan pangan total selama satu hari. Ini berarti, sarapan pagi menurunkan asupan pangan dan energi total. Dan juga hasil penelitian Divisi Kedokteran Pencegahan Fakultas Kedokteran Universitas Massachusetts membuktikan bahwa pola makan 3/4 frekuensi makan dan kebiasaan sarapan 3/4 berkaitan erat dengan risiko menderita obesitas. Mereka juga menemukan bahwa makin sering mengonsumsi makanan, makin kecil risiko menderita obesitas. Temuan ini agak bertolak belakang dengan pendapat umum yang selama ini berlaku. "Semakin sering mengkonsumsi makanan mengakibatkan makin banyak energi atau lemak yang dimasukkan ke dalam tubuh". Tetapi hasil yang dipublikasikan dalam American Jurnal of Epidemiology (2008), orang yang mengkonsumsi makanan sampai dengan 3 kali per hari berisiko menderita obesitas $45 \%$ lebih tinggi dari pada orang yang menkonsumsi makan 4 kali atau lebih. Hal ini berkaitan dengan sekresi insulin yang tinggi. Makin banyak insulin yang disekresikan, makin besar hambatan pada aktifitas enzim lipase. Akibatnya, makin banyak lemak yang ditimbun di dalam tubuh. Peter Richel menemukan hasil dari penelitian pada 2.000 remaja (selama 5tahun), bahwa semakin sering anak remaja sarapan, semakin kecil kemungkinan mengalami obesitas atau kelebihan berat badan. Hal yang terjadi juga adalah presentase lemak total dan lemak jenuh ditemukan lebih rendah pada anak yang sarapan dibandingkan yang tidak. Orang yang mengisi perutnya sebelum berangkat ke kantor atau ke sekolah biasanya tidak akan makan lagi hingga makan siang tiba. Sebaliknya, mereka yang membiarkan perutnya kosong akan mencari cemilan untuk mengganjal perutnya berupa kue atau biskuit yang mengandung gula yang tinggi. Hal inilah yang menjadi masalah. Walaupun dari hasil analisis mendukung teori bahwa sarapan pagi secara teratur menurunkan risiko obesitas, tetapi perlu dilakukan penelitian lebih mendalam.

\section{Kesimpulan dan Saran}

Berdasarkan data dan analisis yang sudah dilakukan maka dapat dibuat kesimpulan yaitu :

1. Proporsi obesitas pada anak sekolah menengah atas di kota Gorontalo adalah $10,19 \%$

2. Besar risiko kejadian obesitas 
berdasarkan aktifitas fisik (olahraga) adalah 2,939; yang berarti siswa yang aktifitas fisiknya rendah berisiko 2,939 kali untuk mengalami obesitas dibandingkan dengan siswa yang aktifitas fisiknya tinggi

3. Besar risiko kejadian obesitas berdasarkan riwayat kegemukan adalah 2,753; yang berarti siswa yang orang tuanya mempunyai riwayat kegemukan berisiko 2,753 kali untuk mengalami obesitas dibandingkan dengan siswa yang orang tuanya tidak mempunyai riwayat kegemukan

4. Besar risiko kejadian obesitas berdasarkan konsumsi fast food adalah 2,705; yang berarti siswa yang mengkonsumsi fast

food 3 kali / minggu berisiko 2,705 kali untuk mengalami obesitas dibandingkan dengan siswa yang mengkonsumsi fast food $<3$ kali $/$ minggu

5. Besar risiko kejadian obesitas berdasarkan lama tidur malam adalah 2,020; yang berarti siswa yang lama tidur $<8,5$ jam / malam berisiko 2,020 kali untuk mengalami obesitas dibandingkan dengan siswa yang lama tidur 8,5 jam / malam

6. Besar risiko kejadian obesitas berdasarkan sarapan pagi adalah 2,449; yang berarti siswa yang sarapan pagi $<4$ kali / minggu berisiko 2,449 kali untuk mengalami obesitas dibandingkan siswa yang sarapan pagi 4 kali / minggu

7. Faktor risiko yang paling berisiko adalah olahraga dibandingkan dengan variable lainnya.

8. Disarankan kepada pemerintah dan instansi terkait untuk segera menyusun rencana program penaggulangan obesitas khususnya obesitas pada remaja di provinsi Gorontalo

\section{Ucapan Terima Kasih}

Penulis menyampaikan terima kasih kepada seluruh pihak yang membantu dalam penelitian ini, tim enumerator dan Kepala Dinas Kesehatan Provinsi Gorontalo

\section{DAFTAR PUSTAKA}

1. Adnyana, Ketut. 2005. Obesitas Sebagai Masalah Kesehatan. Bandung : Departemen Farmasi FMIPA ITB pp. 30- 35

2. Arief, Mochammad. 2004. Pengantar Metodelogi Penelitian Untuk Ilmu Kesehatan. Klaten Selatan : CSGF pp 71- 76

3. Arikunto S. 2006. Prosedur Penelitian : Suatu Pendekatan Praktek. Jakarta : PT. Rineke Cipta Battegay, Edouard J. LIP,

4. Gregory L.H. Bakris, George S. 2005. Hypertension : Principles And Practice : 
Definition And Classification Hypertension . United States of America : Taylor \& Francis Group pp. 17

5. Behrmann, Kliegman, Arvin. 2000. Nelson Ilmu Kesehatan Anak : Sistem Kardiovaskuler. Jakarta : EGC pp. 15491550

6. CDC, 2010.About BMI for Children and Teens. Diakses pada 17 Maret 2011 dari http://www.cdc.gov/healthyweight/assessin g/bmi/childrens_bmi/about_childrens bmi.html

7. CDC, 2000. CDC BMI-for-age growth charts for girls and boys.diakses pada tanggal 17 Maret 2011 dari http://www.cdc.gov/nchs/data/series/sr 11/sr11_246.pdf.

8. Kamso S, Rumawas JS, Lukito W, et al. 2007. Determinants of blood pressure

9. Guyton, Arthur C\& Hall Ph.D, John E. Buku Ajar Fisiologi Kedokteran : Hipertensi Primer. Jakarta :EGC pp.239

10. Hoffman, Julien. 2007. Buku Ajar Pediatri Rudolph Vol. 3 : Hipertensi Arterial Sistemik. Jakarta : EGC pp. 1697-1698 among Indonesian elderly individuals who are of normal and over-weight: a cross sectional study in an urban population. www.PubMed.com . Download tanggal 17. Agustus 2010 Vol.25 No.11:2317-24

9. Kaplan, Bernard s. 2005. Pedoman Klinis Pediatri : Hipertensi. Jakarta : EGC pp. 416-420

11. Kaufmann, Gilbert R. 2005. Hypertension : Principles And Practice : Epydemiology Of Hypertension. United States of America : Taylor \& Francis Group pp. 24

12. Khomsan, Ali. 2003. Pangan dan Gizi untuk Kesehatan. Jakarta : PT Raja Grafindo pp. 90

13. Kumar, Vinay, Cotran, et al. 2007. Buku Ajar Patologi Anatomi Edisi 7 Vol. 2. Jakarta : EGC pp 367-378 